УДК 340.131:342.9.03(470)

DOI dx.doi.org/10.24866/1813-3274/2019-3/82-99

С. Д. Князев ${ }^{1}$,

Дальневосточный федеральный университет, Владивосток

Конституционный суд Российской Федерации, Санкт-Петербург

E-mail:knyazev@ksrf.ru

\title{
АДМИНИСТРАТИВНАЯ ОТВЕТСТВЕННОСТЬ В РЕШЕНИЯХ КОНСТИТУЦИОННОГО СУДА РОССИЙСКОЙ ФЕДЕРАЦИИ (К ВОПРОСУ О КОНЦЕПТУАЛЬНОМ РЕФОРМИРОВАНИИ КОДЕКСА РОССИЙСКОЙ ФЕДЕРАЦИИ ОБ АДМИНИСТРАТИВНЫХ ПРАВОНАРУШЕНИЯХ)
}

Аннотация. В статье на основе анализа конституционных принципов публично-правовой ответственности и сформулированных Конституционным Судом Российской Федерации правовых позиций, касающихся различных вопросов ответственности за административные правонарушения, рассматриваются приоритетные, по мнению автора, направления совершенствования законодательства об административной ответственности. При этом главное внимание уделяется проблемам обеспечения полномасштабной кодификации административной ответственности, разграничения нормотворческих полномочий Российской Федерации и её субъектов в административно-деликтной сфере, понятию административного правонарушения, в том числе в его соотношении с преступлением, административной ответственности юридических лиц, системе административных наказаний и правилам их применения.

Ключевые слова: Конституционный Суд Российской Федерации, законодательство об административной ответственности, административное правонарушение, административная ответственность юридических лиц, административное наказание, срок давности административной ответственности.

\footnotetext{
1 Сергей Дмитриевич Князев, судья Конституционного Суда Российской Федерации (г. СанктПетербург); доктор юридических наук, профессор, заведующий кафедрой конституционного и административного права Дальневосточного федерального университета, Владивосток, Россия.

Для изитирования: Князев С. Д. Административная ответственность в решениях Конституционного Суда Российской Федерации (к вопросу о концептуальном реформировании Кодекса Российской Федерации об административных правонарушениях) // Азиатско-Тихоокеанский регион: экономика, политика, право. 2019. № 3. С. 82-99.
}

(C) Князев С.Д., 2019 


\section{Sergey D. Knyazev ${ }^{1}$}

Far Eastern Federal University, Vladivostok, Russia

The Constitutional Court of the Russian Federation, St. Petersburg, Russia

E-mail: knyazev@ksrf.ru

\section{ADMINISTRATIVE RESPONSIBILITY IN DECISIONS OF THE CONSTITUTIONAL COURT OF THE RUSSIAN FEDERATION (ON THE ISSUE OF CONCEPTUAL REFORM OF THE CODE OF THE RUSSIAN FEDERATION ON ADMINISTRATIVE OFFENSES)}

Abstract. Based on an analysis of the constitutional principles of public liability and the legal positions formulated by the Constitutional Court of the Russian Federation, the article considers the priority areas for improving the legislation on administrative responsibility. The main attention is paid to the problems of ensuring the full-scale codification of administrative responsibility, delimitation of the legislative powers of the Russian Federation and its subjects in the administrative-tort sphere, the concept of an administrative offense, including in relation to crime, administrative liability of legal entities, the system of administrative penalties and application of their rules.

Keywords: Constitutional Court of the Russian Federation, legislation on administrative responsibility, administrative offense, administrative liability of legal entities, administrative punishment, limitation period of administrative responsibility.

Конституционная характеристика России в качестве правового государства, основополагающей обязанностью которого выступают признание, соблюдение и защита прав и свобод человека и гражданина (ст. 1 и ст. 2 Конституции Российской Федерации), не может не предъявлять повышенных требований к конституционным стандартам административной ответственности [14, с. 43], тем более что она рассчитана на применение не только к физическим, но и к юридическим лицам, сопряжена с предоставлением обширных юрисдикционных полномочий, наряду с судебными органами, значительному числу представителей исполнительной власти и предполагает возможность её законодательного установления как на федеральном

\footnotetext{
${ }^{1}$ Sergey D. Knyazev, judge of the Constitutional Court of the Russian Federation (St. Petersburg); Doctor of Law, Professor, Head of the Department of Constitutional and Administrative Law, Far Eastern Federal University, Vladivostok, Russia.

For citing: Knyazev S. D. Administrative responsibility in decisions of the Constitutional Court of the Russian Federation (on the issue of conceptual reform of the Code of the Russian Federation on administrative offenses) // PACIFIC RIM: Economics, Politics, Law. 2019. No 3. P. 82-99.
} 
уровне, так и на уровне субъектов Российской Федерации [8, с. 16]. Однако несмотря на то, что с момента принятия действующего Кодекса Российской Федерации об административных правонарушениях минуло уже более пятнадцати лет, приходится констатировать: современное состояние административной ответственности едва ли в полной мере отвечает конституционным принципам и нормам, подтверждением чему могут служить, помимо прочего, поступающие в Конституционный Суд России обращения, в которых подвергаются сомнению, по сути, все аспекты административно-деликтного регулирования.

Анализ принятых Судом решений красноречиво свидетельствует, что зачастую конституционные дефекты административной ответственности обусловливаются отсутствием до настоящего времени надлежащей ясности в вопросе о сущности, юридической природе и предназначении этого вида ответственности, особенно в соотношении с ответственностью уголовной. Как следствие, Конституционный Суд России при рассмотрении обращений, в которых оспаривается конституционность тех или иных положений законодательства об административных правонарушениях, считает своим долгом неизменно фокусировать внимание законодательной власти на общеправовых принципах публично-правовой ответственности, очерчивающих пределы её дискреционных полномочий в сфере правового регулирования административной ответственности.

Если суммировать сформулированные им относительно содержания указанных принципов правовые позиции (постановления Конституционного Суда Российской Федерации от 15 июля 1999 г. № 11-П, от 19 марта 2003 г. № 3-П, от 13 июля 2010 г. № 15-П, от 17 января 2013 г. № 1-П, от 14 февраля 2013 г. № 4-П, от 10 февраля 2017 г. № 2-П и др.), можно прийти к выводу, согласно которому российский конституционный правопорядок сегодня немыслим без признания того, что:

юридическая ответственность может наступать только за те деяния, которые законом, действующим на момент их совершения, признаются правонарушениями; использование различных видов юридической ответственности должно согласовываться с конституционными принципами демократического правового государства, включая требование справедливости, в его взаимоотношениях с физическими и юридическими лицами как субъектами ответственности; общепризнанным принципом привлечения к ответственности во всех отраслях права является наличие вины - либо доказанной, либо презюмируемой, но опровержимой - как элемента субъективной стороны состава правонарушения, а всякое исключение из него должно быть выражено прямо и недвусмысленно, т.е. предусмотрено непосредственно в законе;

закрепляя и изменяя составы правонарушений и меры ответственности, в том числе административной, за их совершение, федеральный законодатель связан вытекающими из статьи 55 (часть 3) Конституции Российской Федерации критериями необходимости, пропорциональности и соразмерности ограничения прав и свобод граждан конституционно значимым целям, а также обязан соблюдать гарантиро- 
ванное статьёй 19 (часть 1) Конституции Российской Федерации равенство всех перед законом, означающее, что любое правонарушение и санкции за его совершение должны быть чётко определены в законе, причём таким образом, чтобы исходя непосредственно из текста соответствующей нормы - в случае необходимости с помощью толкования, данного ей судами, - каждый мог предвидеть правовые последствия своих действий (бездействия);

конституционные требования справедливости и гуманизма предопределяют необходимость дифференциации юридической ответственности в зависимости от существенных обстоятельств, влияющих на выбор той или иной меры государственного принуждения, а потому, предусматривая для совершивших правонарушение лиц конкретный вид юридической ответственности, федеральный законодатель обязан соотносить его с характером правонарушения, опасностью для находящихся под охраной закона ценностей, личностью и степенью вины правонарушителя, гарантируя тем самым адекватность порождаемых последствий тому вреду, который причинен в результате правонарушения, не допуская избыточного государственного принуждения и обеспечивая баланс прав привлекаемого к ответственности индивида (юридического лица) и публичного интереса, состоящего в защите личности, общества и государства от противоправных посягательств;

виды юридической ответственности и сопутствующие им наказания должны обладать разумным сдерживающим потенциалом, достаточным для соблюдения соответствующих запретов (ограничений); в противном случае их применение не будет отвечать предназначению государственного принуждения, которое, по смыслу статей 1 (часть 1), 2, 17 (часть 3), 18 и 55 (часть 3) Конституции Российской Федерации, заключается, главным образом, в превентивном использовании присущих ему юридических средств для защиты прав и свобод человека и гражданина, иных конституционно признаваемых ценностей гражданского общества и правового государства;

в случаях, когда предусматриваемые законом меры публично-правовой ответственности перестают отвечать социальным реалиям, порождая ослабление защиты конституционно значимых ценностей или, напротив, избыточное применение государственного принуждения, федеральный законодатель вправе обеспечить их приведение в соответствие с новыми вызовами, соблюдая при этом конституционные принципы равенства, справедливости и гуманизма.

Очевидно, что лишь неукоснительное следование всем вытекающим из данных принципов критериям (стандартам) нормативного правового регулирования ответственности за административные правонарушения в состоянии гарантировать соответствие законодательства об административной ответственности Конституции Российской Федерации. Не случайно именно отступления от них, как правило, и являются основной причиной для конституционной дисквалификации тех или иных законоположений. 
Соответственно, любые, а тем более концептуальные, изменения (коррективы) административно-деликтного законодательства должны базироваться на универсальных конституционных стандартах юридической ответственности и не расходиться с правовыми позициями Конституционного Суда, фиксирующими - прямо или косвенно, т.е. посредством выявления обязательного конституционноправового смысла проверяемых норм, - неконституционность тех или иных законодательных решений в сфере административной ответственности*. Иначе использование административно-наказательного принуждения будет вступать в противоречие со статьями 15 (часть 2) и 125 (часть 6) Конституции Российской Федерации, а также статьей 79 Федерального конституционного закона «О Конституционном Суде Российской Федерации», закрепляющих обязательность конституционных норм и непреодолимость юридической силы актов Конституционного Суда для всех без исключения органов законодательной, исполнительной и судебной власти.

Вместе с тем при проведении реформ, в особенности масштабных, законодательства об административных правонарушениях нужно учитывать объективные пределы отечественного судебного конституционного контроля, который не обладает полномочиями самостоятельного инициирования проверок действующего правового, в том числе административно-деликтного, регулирования, а связан рамками (предметом) поступающих обращений (жалоб и запросов). Это обстоятельство существенно осложняет адекватное восприятие решений Конституционного Суда в процессе совершенствования законодательства об административных правонарушениях, поскольку, в отсутствие в них всесторонней оценки конституционности института административной ответственности, законодатель вынужден, реализуя вверенные ему дискреционные полномочия, обеспечивать конституционное качество устанавливаемых норм во многом за счёт критического осмысления всей совокупности сформулированных Конституционным Судом правовых позиций, приобретающих в своём многообразии методологическое (ориентирующее) значение для выработки законодательной политики в области ответственности за административные правонарушения [2, с. 46].

К тому же, в процессе совершенствования правового регулирования административной ответственности нельзя абстрагироваться не только от итоговых решений Конституционного Суда, содержащих негативную конституционную оценку проверенных законоположений, но и от тех его решений, которыми по существу подтверждается конституционность оспоренных административно-деликтных норм. Это связано с тем, что, не находя при предварительном изучении обжалуе-

\footnotetext{
* Это в полной мере касается и выполнения поручения Председателя Правительства Российской Федерации о разработке концепции нового Кодекса Российской Федерации об административных правонарушениях, адресованного им Министерству юстиции Российской Федерации и Министерству экономического развития Российской Федерации на заседании Правительства, состоявшемся 21 марта 2019 г.
} 
мых норм признаков неконституционности, Конституционный Суд тем не менее вовсе не признаёт их в качестве единственно возможного юридического императива и не исключает выбора законодателем иного варианта регламентации соответствующих отношений. Более того, иногда в его решениях напрямую обращается внимание Федерального Собрания на предпочтительность изыскания альтернативных законодательных решений в сфере административной ответственности (определения Конституционного Суда Российской Федерации от 4 апреля 2013 г. № 486-О, от 9 февраля 2016 г. № 213-О и др.).

С учётом этого, опираясь на принятые Конституционным Судом Российской Федерации наиболее резонансные решения (как постановления, так и определения), хотелось бы остановиться на следующих вопросах, имеющих первостепенное значение для определения приоритетных направлений совершенствования законодательства об административных правонарушениях.

Во-первых, по-прежнему весьма актуальной видится проблема «сплошной» или «тотальной» кодификации законодательства об административной ответственности, по крайней мере на федеральном уровне. Как известно, несмотря на директивное указание статьи 1.1 (часть 1) КоАП Российской Федерации на то, что законодательство об административных правонарушениях состоит из данного Кодекса и принимаемых в соответствии с ним законов субъектов Российской Федерации, в действительности с первого дня его вступления в силу нормы об административной ответственности можно обнаружить и в иных федеральных законах, в частности в большом количестве - в Налоговом кодексе Российской Федерации. В результате, вопреки заявленной цели обеспечения действительного единства федерального законодательного регулирования административной ответственности, она до сих пор не утратила нормативной «прописки» не только в КоАП Российской Федерации, но и в других федеральных законах (о банковской деятельности, об обязательном пенсионном страховании и т.п.), что, несомненно, сказывается как на «авторитете» самого Кодекса, так и на качестве административноюрисдикционной деятельности. Не удивительно поэтому, что в юридической доктрине всё настойчивее проводится идея сосредоточения всех федеральных норм об административной ответственности, какой бы сферы она ни касалась, целиком и полностью в КоАП Российской Федерации [6, с. 136-137].

Конституция Российской Федерации, конечно, не предрешает, какой быть федеральной кодификации законодательства об административной ответственности: всеобъемлющей или нет? [5]* . Однако она безусловно обязывает законодательную

\footnotetext{
* Здесь разумно будет заметить, что с точки зрения статьи 72 (часть 1, пункт «к») Конституции Российской Федерации, различающей административное и административно-процессуальное законодательство, принципиально не исключена возможность отдельной систематизации материальных и процессуальных норм об административной ответственности, как это уже имеет место, например, в Республике Таджикистан, где одновременно действуют Кодекс об административных правонарушениях и Процессуальный Кодекс об административных правонарушениях.
} 
власть - независимо от избранного формата такой кодификации - соблюдать конституционные принципы правового регулирования оснований и условий ответственности за административные правонарушения, любое игнорирование которых чревато рисками её произвольного применения. В связи с этим нет нужды доказывать, что указанные риски не могут не возрастать в случае рассредоточения административно-деликтных норм в различных федеральных законах, объективно приводящего к образованию «параллельных» законодательных параметров административной ответственности и неминуемо подразумевающего серьёзную дифференциацию круга субъектов ответственности, её процедур и сроков, перечней применяемых санкций.

В данном контексте уместно обратиться к Постановлению Конституционного Суда Российской Федерации от 4 февраля 2019 г. № 8-П, которым дана оценка допустимости привлечения индивидуального предпринимателя в качестве должностного лица к административной ответственности по статье $15.33^{2}$ КоАП Российской Федерации за непредставление в органы Пенсионного фонда Российской Федерации в установленный законодательством об индивидуальном (персонифицированном) учёте в системе обязательного пенсионного страхования срок сведений (документов), необходимых для ведения индивидуального (персонифицированного) учёта в системе обязательного пенсионного страхования в ситуации, когда он, как страхователь, ранее уже был привлечён за такое бездействие к ответственности, закрепленной в Федеральном законе от 1 апреля 1996 г. № 27-Ф3 «Об индивидуальном (персонифицированном) учёте в системе обязательного пенсионного страхования».

Изучив в рамках соответствующего дела относящееся к оспоренной норме законодательство, Конституционный Суд пришёл к выводу, что применительно к индивидуальным предпринимателям КоАП Российской Федерации и названный Федеральный закон устанавливают - вопреки конституционному принципу non bis in idem (статья 50, часть 1 Конституции Российской Федерации) - возможность их повторного привлечения к однопорядковой (административно-правовой) ответственности за одно и то же правонарушение (нарушение правил предоставления в органы Пенсионного фонда Российской Федерации сведений (данных), необходимых для ведения индивидуального (персонифицированного) учёта в системе обязательного пенсионного страхования). При этом одновременное наступление для индивидуального предпринимателя идентичной, административной по своей юридической природе, ответственности как по статье $15.33^{2}$ КоАП Российской Федерации, так и по Федеральному закону «Об индивидуальном (персонифицированном) учёте в системе обязательного пенсионного страхования» обусловлено ещё и тем, что наличное законодательство не предусматривает никаких изъятий при привлечении их к ответственности в соответствии с названным Кодексом (аналогичных тем, что сделаны, например, в примечании к его статье 15.33). 
Отталкиваясь от этого, Конституционный Суд посчитал необходимым обязать федерального законодателя внести изменения в правовое регулирование административной ответственности за нарушение установленного порядка и сроков представления в органы Пенсионного фонда Российской Федерации сведений (документов) об индивидуальном (персонифицированном) учёте в системе обязательного пенсионного страхования, отдельно обратив его внимание на устранение неопределённости в вопросе о соотношении мер ответственности, предусмотренных частью 3 статьи 17 Федерального закона «Об индивидуальном (персонифицированном) учёте в системе обязательного пенсионного страхования» и статьёй $15.33^{2}$ КоАП Российской Федерации.

И хотя приведённый судебный акт Конституционного Суда России касается частного случая и не ограничивает законодательное усмотрение относительно предпочтительных способов систематизации (кодификации) законодательства об административной ответственности, он тем не менее актуализирует потребность критического осмысления её возможных масштабов.

Во-вторых, обстоятельного исследования требует вытекающая из статей 1 (часть 1), 5, 11 (часть 3), 72 (часть 1, пункт «к») и 76 (часть 2) Конституции Российской Федерации проблема распределения законодательных полномочий в сфере административной ответственности между Российской Федерацией и образующими её субъектами, даже несмотря на то, что она, казалось бы, уже была принципиально решена Конституционным Судом в Определении от 1 октября 1998 г. № 145-О.

Ведь в этом Определении Конституционный Суд, ещё в условиях действия прежнего КоАП РСФСР, признал за субъектами Российской Федерации право принимать собственные законы в области административных правонарушений, если они не противоречат федеральным законам, регулирующим те же правоотношения, попутно указав, что, устанавливая административную ответственность за те или иные деяния, они не могут вторгаться в те сферы общественных отношений, регулирование которых составляет предмет ведения Российской Федерации, а также предмет совместного ведения при наличии по соответствующему вопросу федерального закона, и обязаны соблюдать общие требования, предъявляемые к установлению административной ответственности и к производству по делам об административных правонарушениях.

На этом основывается и действующее законодательство: согласно статьям 1 (часть 1), 1.3 и $1.3^{1}$ КоАП Российской Федерации субъекты Российской Федерации не лишены возможности собственного нормотворчества в сфере правового регулирования ответственности за административные правонарушения. И, как показывает практика, активно ею пользуются, благодаря чему их законы об административной ответственности давно стали привычным атрибутом регионального правового ландшафта. 
В то же время следует заметить, что наделение субъектов Российской Федерации законодательной компетенцией по вопросам административной ответственности вызывает (и не только среди представителей отечественной юридической науки) ощутимое неприятие, продиктованное соображениями его конституционной порочности (несостоятельности). Так, противники передачи соответствующих полномочий субъектам Российской Федерации традиционно порицают региональное законодательство об административной ответственности прежде всего за то, что неотъемлемым признаком такой ответственности является государственное принуждение, сопряжённое с ограничением прав и свобод граждан (юридических лиц), а потому её установление, как это прямо закреплено в статье 55 (часть 3) Конституции Российской Федерации, должно исходить лишь от федеральной власти [15, c. $154 ; 12$, с. $29 ; 7$, с. $27-28]$.

То, что подобные суждения не лишены веских оснований, находит отражение и в решениях Конституционного Суда Российской Федерации (постановления от 14 февраля 2013 г. № 4-П, от 22 апреля 2014 г. № 13-П и др.), в которых он неоднократно вынужден был, касаясь вопросов законодательного регулирования ответственности за административные правонарушения, подчёркивать неразрывную связь административной ответственности, в частности за нарушение установленного порядка организации (проведения) публичного мероприятия или за нарушение правил дорожного движения, с непосредственным ограничением прав и свобод человека и гражданина, которое во исполнение предписаний статей 55 (часть 3 ) и 71 (пункт «в») Конституции Российской Федерации возможно только в соответствии с федеральным законом. Данное обстоятельство, по мнению Суда, означает, что конституционный правопорядок не исключает пересмотра распределения законодательных полномочий в области ответственности за административные правонарушения между Российской Федерацией и её субъектами, в том числе посредством отнесения к федеральному ведению установления рамочных пределов административных наказаний за отдельные административные правонарушения с предоставлением субъектам Федерации возможности их региональной конкретизации.

Говоря о разграничении полномочий по регулированию административной ответственности между федеральным и региональным уровнями власти, не нужно забывать и о том, что принятие законов об ответственности за административные правонарушения является, как отметил Конституционный Суд Российской Федерации в Постановлении от 2 июля 2018 г. № 27-П, правом, а не обязанностью субъектов Российской Федерации. Причём его реализация в сфере охраны общественного порядка и общественной безопасности способна, как показывает послуживший поводом для вынесения указанного Постановления запрос Законодательного Собрания Ростовской области о проверке конституционности абзаца второго части 6 статьи 28.3 КоАП Российской Федерации, породить серьёзные затруднения в органи- 
зации практического применения принятых законов, в том числе из-за отсутствия у субъектов Федерации необходимых организационных, кадровых, материальных и иных ресурсов $[13$, с. $40-45]$.

Всё это диктует потребность максимально взвешенного подхода к определению надлежащего субъекта законодательных полномочий в области административной ответственности с тем, чтобы её правовое регулирование в полной мере согласовывалось с вытекающими из статей 1 (часть 1), 6 (часть 2), 19 (части 1 и 2), 55 (часть 3), 71 (пункт «в») и 72 (часть 1, пункты «б» и «к») Конституции Российской Федерации принципами федеративного правового государства, юридического равенства и допустимости ограничения прав и свобод человека и гражданина только в соответствии с федеральным законом и только при соблюдении требований необходимости, пропорциональности и справедливости.

В-третьих, самого пристального внимания требует уточнение в КоАП Российской Федерации понятия административного правонарушения [11, с. 422-423], тем более что в целом ряде своих решений Конституционный Суд Российской Федерации последовательно придерживается позиции, согласно которой несмотря на схожесть задач, принципов и целей административной и уголовной ответственности, необходимо исчерпывающим образом различать административное правонарушение и преступление; квалифицирующим признаком административного правонарушения является меньшая степень его общественной опасности; конструируя составы административных правонарушений, законодатель должен избегать отнесения к ним деяний, имеющих криминальную степень общественной опасности, подтверждаемую масштабом распространённости и динамикой роста таких деяний, значимостью охраняемых законом ценностей, на которые они посягают, существенностью причиняемого ими вреда, а также невозможностью их преодоления без использования средств уголовной репрессии; повторность административного правонарушения не может сама по себе являться основанием для его «переквалификации» в преступление, поскольку уголовная ответственность предполагает, по общему правилу, что повторное правонарушение должно быть сопряжено с причинением вреда здоровью граждан, имуществу физических или юридических лиц, окружающей среде, иным охраняемым конституционным ценностям или с реальной угрозой его причинения (постановления Конституционного Суда Российской Федерации от 27 июня 2005 г. № 7-П, от 14 июля 2015 г. № 20-П, от 10 февраля 2017 г. № 2-П и др.).

Перечисленные критерии идентификации административных правонарушений приобретают особое значение ещё и потому, что в современных условиях в юридическом сообществе настойчиво продвигается идея выделения - наряду с административным правонарушением и преступлением - такого отдельного основания юридической ответственности, как уголовный проступок, охватывающий своими 
рамками уголовно-противоправные деяния, объективно не нуждающиеся в классическом уголовном реагировании (в частности, не предполагающие применение наказания в виде лишения свободы и не заслуживающие возникновения у лиц, подвергнутых ответственности за их совершение, состояния судимости) ${ }^{*}$. Не вдаваясь в подробное их обсуждение, нельзя всё же не отметить, что реализации этой идеи неминуемо должно предшествовать обстоятельное исследование вопросов, касающихся соотношения уголовных проступков с административными правонарушениями, возможности «перевода» в разряд уголовных проступков не только соответствующих уголовно-противоправных деяний, но и некоторых административных правонарушений, тяготеющих по характеру и степени общественной опасности к преступлениям, а также целесообразности сохранения составов преступлений с административной санкцией [1].

В критическом восприятии нуждается и отсутствие в действующем КоАП Российской Федерации полноценного института соучастия в совершении административного правонарушения, так как по смыслу статьи 4.3 (часть 1, пункт 4) данного Кодекса единственной его формой может быть лишь соисполнительство (совместное совершение административного правонарушения двумя и более лицами), квалифицируемое как одно из обстоятельств, отягчающих административную ответственность. Следствием такого законодательного решения является обнаружившаяся проблема «легального ухода» от ответственности тех, кто, непосредственно не нарушая административно-правовые запреты (правила), вовлечён в административно-противоправную деятельность путём преднамеренного создания условий для совершения административных правонарушений иными лицами. В итоге указанные лица сами остаются безнаказанными, а принадлежащие им на праве собственности машины, механизмы и другие предметы (объекты) используемые в качестве орудий совершения административного правонарушения другими лицами, оказываются, по общему правилу, «застрахованными» от конфискации, предусмотренной статьёй 3.7 КоАП Российской Федерации.

На необходимость исправления сложившегося положения Конституционный Суд Российской Федерации вынужден был обратить внимание федерального законодателя в Постановлении от 25 апреля 2011 г. № 6-П, принятом по итогам проверки части 1 статьи 3.7 и части 2 статьи 8.28 КоАП Российской Федерации в связи с жалобой ООО «СтройКомплект», когда, объявив неконституционным применение за незаконную рубку леса конфискации орудия совершённого административного правонарушения в отношении лица, не привлечённого к административной ответственно-

\footnotetext{
* 20 декабря 2018 года Верховным Судом Российской Федерации в Государственную Думу был внесён законопроект, предусматривающий введение в уголовное и уголовно-процессуальное законодательство понятия уголовного проступка, выделение которого из общей массы преступлений должно, по мнению Верховного Суда, поспособствовать либерализации проводимой уголовной политики.
} 
сти и не признанного в законной процедуре виновным в совершении соответствующего административного правонарушения, не исключил установления административного наказания собственника лесозаготовительной техники, а стало быть и возможности конфискации этой техники, если она была передана другим лицам с целью незаконной рубки лесных насаждений, т.е. по существу за пособничество.

Думается, федеральному законодателю, в особенности учитывая складывающуюся в различных сферах общественных отношений, находящихся под защитой законодательства об административной ответственности, обстановку, характеризующуюся активным использованием присущих ему пробелов, нередко позволяющих гражданам (юридическим лицам), занимающимся той или иной предпринимательской деятельностью, нарушать закон «чужими руками» и при этом избегать привлечения к ответственности и назначения эффективных административных санкций, было бы полезно переосмыслить занятую им относительно института соучастия в совершении административных правонарушений правовую позицию.

В-четвёртых, не стоит забывать о вопросах законодательного оформления административной ответственности юридических лиц, которые связаны с правовыми нюансами установления их виновности в совершении административного правонарушения [4, с. 18-19]*, а также определения принципиальной допустимости распространения административной деликтоспособности на все без исключения категории (виды) юридических лиц, в том числе на органы публичной - государственной и муниципальной - власти.

В Определении от 24 сентября 2013 г. № 1397-О Конституционный Суд посчитал, что, поскольку органы местного самоуправления обладают правами юридического лица и являются полноправными участниками публичных правоотношений, а КоАП Российской Федерации не содержит каких-либо исключений для таких органов в вопросах административной ответственности, то применение к ним административных наказаний не может рассматриваться как противоречащее Конституции России, предусматривающей равенство всех перед законом и судом (статья 19, часть 1). Тем не менее это не означает принципиального запрета противоположного законодательного решения; не случайно в указанном Определении специально отмечено, что существование административной ответственности органов публичной власти предопределено не Конституцией Российской Федерации, а действующим КоАП Российской Федерации, не предусматривающим для них какого-либо юрисдикционного «иммунитета».

Органы власти и местного самоуправления действительно наделяются законодательством правами юридического лица, но это едва ли автоматически превращает их в обычные коммерческие или некоммерческие организации (статья 50 Граждан-

\footnotetext{
* Нередко отсутствие должной ясности относительно вины юридических лиц вызывает полное неприятие их административной ответственности по мотивам объективного вменения и формализма.
} 
ского кодекса Российской Федерации). Привлечение же к административной ответственности фактически уравнивает их с такими организациями; в результате за действия (бездействие), имевшие место со стороны коллективного (коллегиального) субъекта публичной власти, административные санкции, по сути, возлагаются на участника гражданского оборота. Если добавить к этому, что государственные и муниципальные органы вынуждены уплачивать административные штрафы, подлежащие зачислению в федеральный (региональный) бюджет, из тех же самых бюджетных средств, то нельзя не задуматься над экономической, как, впрочем, и социальной, целесообразностью их привлечения к административной ответственности. В связи с этим представляется, что высказанные в юридической литературе настойчивые предложения об отказе от административной ответственности органов государственной власти и местного самоуправления (не исключающем усиления ответственности их должностных лиц) $[9$, с. $11 ; 3$, с. $81 ; 10$, с. 43-44], имея ввиду ещё и соответствующие зарубежные практики, заслуживают, как минимум, тщательного изучения.

Применительно к административной ответственности юридических лиц также требует упоминания и правовая позиция Конституционного Суда Российской Федерации, сформулированная им в Постановлении от 25 февраля 2014 г. № 4-П, согласно которой указание части 1 статьи 1.4 КоАП Российской Федерации на то, что юридические лица подлежат административной ответственности независимо от места нахождения, организационно-правовых форм, подчинённости и других обстоятельств, приводит к унификации такой ответственности по отношению ко всем юридическим лицам, включая субъекты малого предпринимательства, некоммерческие (медицинские, культурные, образовательные и т.п.) организации, государственные и муниципальные учреждения. Это, в свою очередь, негативно сказывается на обеспечении индивидуализации применяемых санкций, вследствие чего законодателю не мешало бы задуматься над дифференциацией размеров административных штрафов для различных категорий (видов) юридических лиц.

В какой-то мере данная правовая позиция уже нашла отражение в КоАП Российской Федерации: Федеральным законом от 3 июля 2016 г. № 316-Ф3 он дополнен статьёй $4.1^{1}$, установившей - при определённых условиях - возможность применения к лицам, являющимся субъектами малого и среднего предпринимательства, а также к их работникам за впервые совершённое административное правонарушение вместо административного штрафа предупреждения, даже если оно не предусмотрено соответствующей статьёй Особенной части Кодекса. Позитивно оценивая эту законодательную новеллу, нужно всё-таки заметить, что она не исчерпывает собой всех имеющихся в распоряжении федерального законодателя ресурсов дифференциации административной ответственности юридических лиц, что, в частности, усматривается из продолжающих поступать в Конституционный 
Суд обращений, направленных на признание специфики административной деликтоспособности и в отношении других, не упомянутых в статье $4.1^{1}$ КоАП Российской Федерации субъектов, в том числе юридических лиц (определения Конституционного Суда Российской Федерации от 21 сентября 2017 г. № 1790-О и от 10 октября 2017 г. № 2255-О).

В-пятых, при оценке приоритетных направлений реформы законодательства об административной ответственности, опираясь на вытекающие из статей 1 (часть 1), 19 (части 1 и 2) и 55 (часть 3) Конституции Российской Федерации требования, согласно которым ограничение прав и свобод может быть оправдано, только если оно необходимо и соразмерно (пропорционально) интересам защиты соответствующих конституционных ценностей, немаловажно не упускать из поля зрения также систему административных наказаний, а также правила их наложения.

Многочисленные изменения и дополнения, внесённые в КоАП Российской Федерации после его принятия, свидетельствуют о склонности законодательной власти к усилению административных санкций, что проявляется в существенном повышении размеров административных штрафов, зачастую имеющих, к тому же, безальтернативный и абсолютно определённый (фиксированный) характер, установлении новых, ощутимо отличающихся своей строгостью наказаний в виде административного приостановления деятельности, обязательных работ и административного запрета на посещение мест проведения официальных спортивных соревнований в дни их проведения.

В таких условиях соблюдение конституционных требований пропорциональности и соразмерности применяемых к нарушителям административных санкций и обеспечение на этой основе справедливой индивидуализации их административной ответственности порой испытывает, в том числе из-за несовершенства установленных в КоАП Российской Федерации правил, труднопреодолимые преграды. Некоторые из них, а именно отсутствие у субъекта административной юрисдикции полномочий по наложению административного штрафа ниже его минимального предела, предусмотренного за конкретное административное правонарушение, по поручению Конституционного Суда России (постановления от 17 января 2013 г. № 1-П, от 14 февраля 2013 г. № 4-П и от 8 апреля 2014 г. № 10-П) в настоящее время устранены федеральным законодателем; однако в целом ситуацию вряд ли можно считать исправленной. Ведь в упомянутых постановлениях Конституционный Суд Российской Федерации, ориентируя законодательную власть на поиск разумных решений, способствующих полноценной реализации принципа индивидуализации административной ответственности при применении административных наказаний, не ограничивался указанием лишь на возможность предоставления компетентным органам (должностным лицам) права назначения административного штрафа ниже низшего предела. Помимо этого, он недвусмысленно «намекал» Федеральному Собранию на такие возможные меры, 
как законодательное снижение минимальных размеров административных штрафов, установление альтернативных (более мягких) санкций, более активное использование института освобождения нарушителя от административной ответственности или административного наказания в случае его деятельного раскаяния. В силу этого преодоление риска неконституционных издержек, детерминируемых присущими наличной системе административных наказаний и правилам их наложения недостатками, требует от федерального законодателя принятия дальнейших усилий по совершенствованию соответствующего блока административно-деликтных норм.

Ещё одним аспектом правового регулирования административной ответственности, касающимся условий применения административных наказаний и нуждающимся в корректном законодательном обеспечении, является надлежащее закрепление срока давности привлечения к административной ответственности (статья 4.5 КоАП Российской Федерации). В этом плане было бы полезно критически оценить общий (двухмесячный, а по делу об административном правонарушении, рассматриваемому судьёй, - трёхмесячный) и специальные сроки (один год, два года, три года, шесть лет) давности административной ответственности, а также их соотношение как друг с другом, так и со сроками давности уголовной ответственности, которые, как это следует из части 1 статьи 78 Уголовного кодекса Российской Федерации, за преступления небольшой тяжести составляют два года (пункт «а»), а за преступления средней тяжести - шесть лет (пункт «б»). И хотя уголовный закон вследствие возможности приостановления течения установленных им сроков давности - допускает их увеличение, а КоАП Российской Федерации - нет (единственное исключение рассчитано на случаи удовлетворения ходатайства лица, в отношении которого ведется производство по делу об административном правонарушении, о рассмотрении дела по месту жительства данного лица), едва ли совпадение специальных сроков давности административной ответственности со сроками привлечения к уголовной ответственности за преступления небольшой и средней тяжести не может не вызывать никаких вопросов.

Закрепляя специальные сроки давности привлечения к административной ответственности, статья 4.5 КоАП Российской Федерации увязывает их либо с отдельными видами нарушений законодательства Российской Федерации и таможенного законодательства Таможенного союза в рамках ЕАЭС, либо с нарушениями конкретных статей или частей статей Особенной части данного Кодекса, либо с административными правонарушениями, влекущими применение административного наказания в виде дисквалификации. Такое различие в критериях выделения специальных сроков давности привлечения к административной ответственности, как отметил Конституционный Суд Российской Федерации в Постановлении от 15 января 2019 г. № 3-П, не выходит за конституционные пределы законодательной дискреции; тем не менее с точки зрения юридической техники их соотнесение с 
конкретными составами административных правонарушений или с определёнными видами административных санкций предпочтительнее в том смысле, что, по сути, не оставляет места для неоднозначной правоприменительной трактовки соответствующих правил, порождающей угрозу произвольного привлечения к административной ответственности по прошествии установленного срока давности. Следуя данной логике, можно было бы - в особенности учитывая то обстоятельство, что часть 3 статьи 2.1 КоАП Российской Федерации не исключает «перекрёстной» административной ответственности юридических лиц и уголовной ответственности физических лиц, - подумать о выделении специальных сроков давности административной ответственности, адресованных юридическим лицам (например, в случае привлечения их должностных лиц к уголовной ответственности).

В заключение важно подчеркнуть: проблема совершенствования законодательства об административной ответственности настолько объёмна и многогранна, что затронутые вопросы являют собой лишь малую её часть и, безусловно, не исчерпывают значения правовых позиций Конституционного Суда Российской Федерации, сформулированных им относительно оценки конституционности административноделиктных норм. Однако успех концептуального реформирования КоАП Российской Федерации не представляется возможным в отрыве от их решения.

\section{Список литературы}

1. Административная преюдиция в уголовном праве: казус Ильдара Дадина // Закон. - 2017. - № 2. - С. 21-29.

2. Арановский, К. В. Ненапрасное конституционное правосудие / К. В. Арановский, С. Д. Князев // Судья. - 2017. - № 12. - С. 40-47.

3. Винницкий, А. В. О необходимости законодательного закрепления института юридических лиц публичного права // Журнал российского права. - 2011. № 5. - С. 81-90.

4. Дугенец, А. С. Административная ответственность в российском праве : автореф. дис. ... д-ра юрид. наук : 12.00.14 / А. С. Дугенец ; Рос. правовая акад. М-ва юстиции РФ. - Москва, 2005. - 34 с.

5. Ибрагимов, С. И. Материальное и процессуальное законодательство об административной ответственности в Республике Таджикистан // Публичное право сегодня. - 2018. - № 3. - С. 80-85.

6. Кирин, А. В. О некоторых аспектах концепции развития административного законодательства в Российской Федерации // Современные концепции административного права и процесса: теория и практика. - Челябинск, 2017. - С. 136-137.

7. Князев, С. Д. Административно-правовой статус российских граждан: конституционно-правовые основы реформирования // Журнал российского права. 2004. - № 2. - С. 23-29. 
8. Князев, С. Д. Конституционные стандарты административной ответственности в правовой системе Российской Федерации // Административное право и процесс. - 2014. - № 2. - С. 16-22.

9. Морозова, Н. А. Административная ответственность юридических лиц: история, теория, практика : автореф. дис. ... канд. юрид. наук : 12.00.14 / Н. А. Морозова ; Урал. гос. юрид. акад. - Екатеринбург, 2004. - 22 с.

10. Панов, А. Б. Административная ответственность юридических лиц / А. Б. Панов. - Москва : Норма, 2014. - 192 с.

11. Реформа административной ответственности в России / под общ. ред. А. В. Кирина, В. Н. Плигина. - Москва : Изд. дом Высш. шк. экономики, 2018. 477 c. - ISBN 978-5-7598-1775-8.

12. Россинский, Б. В. Административная ответственность : курс лекций / Б. В. Россинский. - Москва : Норма, 2004. - 448 с.

13. Рукавишникова, И. В. О совершенствовании правового регулирования разграничения предметов ведения Российской Федерации и субъектов Российской Федерации в области законодательства об административных правонарушениях // Публичное право сегодня. - 2018. - № 3. - С. 38-43.

14. Старилов, Ю. Н. Значение стандартов конституционного регулирования и конституционных гарантий для модернизации российского административного права // Журнал конституционного правосудия. - 2013. - № 6. - С. 43-53.

15. Шишунова, Е. В. Разграничение компетенции между Российской Федерацией и её субъектами по установлению административной ответственности: сравнительный анализ положений КоАП РСФСР и КоАП РФ // Административное и информационное право. - Москва, 2003. - С. 140-154.

\section{References}

1. Administrativnaya preyuditsiya v ugolovnom prave: kazus Il'dara Dadina [Administrative prejudice in criminal law: the case of Ildar Dadin]. Zakon, 2017, no. 2, pp. 21-29.

2. Aranovsky K.V., Knyazev S.D. Nenaprasnoe konstitutsionnoe pravosudie [Vain constitutional justice]. Sud'ya, 2017, no. 12, pp. 40-47.

3. Vinnitsky A.V. O neobkhodimosti zakonodatel'nogo zakrepleniya instituta yuridicheskikh lits publichnogo prava [On the need for legislative consolidation of the institute of legal entities of public law]. Zhurnal rossiiskogo prava, 2011, no. 5, pp. 81-90.

4. Dugenets A.S. Administrativnaya otvetstvennost' $v$ rossiiskom prave [Administrative responsibility in Russian law]. Doct. Dis. (Legal Sci.). Synopsis. Moscow, 2005. 34 p.

5. Ibragimov S.I. Material'noe i protsessual'noe zakonodatel'stvo ob administrativnoi otvetstvennosti v Respublike Tadzhikistan [Material and procedural legislation on administrative responsibility in the Republic of Tajikistan]. Publichnoe pravo segodnya, 2018, no. 3 , pp. $80-85$. 
6. Kirin A. V. O nekotorykh aspektakh kontseptsii razvitiya administrativnogo zakonodatel'stva $\mathrm{v}$ Rossiiskoi Federatsii [On some aspects of the concept of the development of administrative legislation in the Russian Federation]. In: Sovremennye kontseptsii administrativnogo prava i protsessa: teoriya i praktika [Modern concepts of administrative law and process: theory and practice]. Chelyabinsk, 2017, pp. 136-137.

7. Knyazev S. D. Administrativno-pravovoi status rossiiskikh grazhdan: konstitutsionno-pravovye osnovy reformirovaniya [Administrative and legal status of Russian citizens: constitutional and legal foundations of reform]. Zhurnal rossiiskogo prava, 2004, no. 2, pp. 23-29.

8. Knyazev S. D. Konstitutsionnye standarty administrativnoi otvetstvennosti v pravovoi sisteme Rossiiskoi Federatsii [Constitutional standards of administrative responsibility in the legal system of the Russian Federation]. Administrativnoe pravo i protsess, 2014, no. 2, pp. 16-22.

9. Morozova N. A. Administrativnaya otvetstvennost' yuridicheskikh lits: istoriya, teoriya, praktika [Administrative responsibility of legal entities: history, theory, practice]. Cand. Dis. (Legal Sci.). Synopsis. Ekaterinburg, 2004. 22 p.

10. Panov A. B. Administrativnaya otvetstvennost' yuridicheskikh lits [Administrative liability of legal entities]. Moscow: Norma Publ., 2014. 192 p.

11. Kirin A. V., Pligin V. N., eds. Reforma administrativnoi otvetstvennosti v Rossii [Reform of administrative responsibility in Russia]. Mosow: High School of Economics Publ., 2018. - 477 p. - ISBN 978-5-7598-1775-8.

12. Rossinsky B. V. Administrativnaya otvetstvennost': kurs lektsii [Administrative responsibility: a course of lectures]. Moscow: Norma Publ., 2004. 448 p.

13. Rukavishnikova I. V. O sovershenstvovanii pravovogo regulirovaniya razgranicheniya predmetov vedeniya Rossiiskoi Federatsii i sub"ektov Rossiiskoi Federatsii v oblasti zakonodatel'stva ob administrativnykh pravonarusheniyakh [On improving the legal regulation of the delimitation of subjects of jurisdiction of the Russian Federation and the subjects of the Russian Federation in the field of legislation on administrative offenses]. Publichnoe pravo segodnya, 2018, no. 3, pp. 38-43.

14. Starilov Yu. N. Znachenie standartov konstitutsionnogo regulirovaniya i konstitutsionnykh garantii dlya modernizatsii rossiiskogo administrativnogo prava [The value of constitutional regulation standards and constitutional guarantees for the modernization of Russian administrative law]. Zhurnal konstitutsionnogo pravosudiya, 2013, no. 6, pp. 43-53.

15. Shishunova E. V. Razgranichenie kompetentsii mezhdu Rossiiskoi Federatsiei i ee sub"ektami po ustanovleniyu administrativnoi otvetstvennosti: sravnitel'nyi analiz polozhenii KoAP RSFSR i KoAP RF [Delineation of competence between the Russian Federation and its subjects in establishing administrative responsibility: a comparative analysis of the provisions of the Administrative Code of the RSFSR and the Administrative Code of the Russian Federation]. In: Administrativnoe i informatsionnoe pravo [Administrative and information law]. Moscow, 2003, pp. 140-154. 